\title{
SISTEM SMART HEALTHCARE MENGGUNAKAN AD8232 BERBASIS BERBASIS INTERNET OF THINGS
}

\author{
${ }^{1}$ ARAFAT, M.KOM \\ ${ }^{2}$ WAGINO, S.KOM, M.KOM \\ ${ }^{1}$ Teknik Informatika , Teknologi Informasi \\ aaruniska@gmail.com \\ ginouniska@gmail.com
}

\begin{abstract}
ABSTRAK
Pemantauan data secara terus-menerus dengan teknologi IOT akan menjadi sebuah platform untuk industri kesehatan, yang mana akan memungkinkan dokter dengan cepat dan efektif untuk mendiagnosis kesehatan pasien nya.Sistem monitoring pasien secara real time akan mengirimkan data yang dipantau langsung kedalam jaringan ke internet. IOT untuk Healthcare dapat digunakan pada pasien kritis yang perlu berada di bawah pemantauan secara terus-menerus; terutama jika tidak ada atau tidak tersedianya dokter di daerah pasien tinggal. Deteksi dini penyakit dimungkinkan dengan menggunakan aplikasi IoT Healthcare dan dokter dapat segera diberitahu. IOT healthcare memiliki berbagai macam aplikasi seperti pemantauan jantung, pemantauan EKG, pemantauan tekanan darah, dll. Pada penelitian ini akan membahas tentang pemantauan ECG dengan IoT dan metodologi implementasinya. Proposal ini mengusulkan dan mengimplementasikan aplikasi smart healtcare menggunakan sistem IOT menggunakan sensor denyut jantung AD8232 yang dihubungkan dengan board NodeMcu dan selanjutnya terhubung ke Cloud Server blynk.
\end{abstract}

Kata kunci: AD8232, IoT, ESP8266, HTTP, Cloud, heart rate monitoring, blynk

\section{PENDAHULUAN}

Kemajuan teknologi menciptakan kemungkinan baru dalam pelayanan kesehatan dan penyembuhan penyakit. Kesehatan sudah menjadi kebutuhan utama bagi manusia tetapi masih merupakan barang yang mahal sehingga untuk menikmati hal tersebut di butuhkan keinginan dan kemauan yang keras. Saat ini kesehatan menjadi fokus utama berbagai studi kasus dan proyek peningkatan pelayanan kesehatan sebagai dasar sistem pelayanan kesehatan secara umum. Sistem tersebut memberikan informasi kepada pasien dan tenaga paramedis melewati batas lokasi masing-masing. Pemanfaatan Internet Of Things dan benda pintar seperti sensor dan peralatan portable membuat sistem smart healthcare bisa dikembangkan. IoT mendukung sistem smart healthcare untuk melacak dan merekam data pribadi pasien. Perangkat sistem Smart Healthcare ini dirancang dengan tujuan yang memungkinkan data pribadi akan segera tersedia untuk individu yang akan dianalisis. Manfaat terbesar dari smart healthcare sistem ini adalah mengurangi kebutuhan akan rumah sakit oleh pihak ketiga untuk menjalankan tes, yang mahal dan panjang. Perangkat ini merupakan kemajuan penting dalam hal pelayanan kesehatan,dengan teknologi internet of things memungkinkan sistem ini memberikan peringatan dini terkait kondisi kesehatan seseorang. Rancangan sistem smart healthcare ini menggunakan hardware murah dan perangkat lunak open source sehingga memungkinkan pengembangan sistem ini untuk keperluan masyarakat umum.

Di indonesia populasi penduduk terus meningkat, perawatan kesehatan dan pemantauan yang akurat menjadi masalah yang serius karena jumlah doktor yang terbatas tidak sebanding dengan jumlah populasi penduduk. Terbatasnya jumlah dokter spesialis atau dokter ahli, membuat masyarakat tidak dapat merasakaan pelayanan dari dokter ahli tersebut. Belum lagi dokter tersebut sering pergi keluar kota, membuat pasien terbengkalai, dengan adanya sistem samrt healtcare kondisi pasien dapat selalu termonitoring oleh dokter dari mana saja.

\section{Rumusan masalah}

Berdasarkan latar belakang judul yang dipilih, maka perumusan masalah adalah :

1. Bagaimana membuat alat smart healthcare yang memiliki kemampuan untuk 
mengukur detak jantung menggunakan modul IoT?

2. Bagaimana membuat dan menghubungkan Sistem Smart Healthcare menggunakan AD8232 Berbasis Internet of Things dengan menggunakan internet melalui webservice?

3. Bagaimana cara merancang dan mengimplementasikan web service IoT untuk Sistem Smart Healthcare menggunakan AD8232 Berbasis Internet of Things ?

\section{Tujuan dan Target Luaran}

Tujuan dari penelitian ini adalah:

1. Membuat alat smart healthcare pada media yang memiliki kemampuan untuk melihat detak jantung dan melaporkan nilai detak jantung menggunakan modul nodemcu.

2. Menghubungkan modul nodemcu dan sensor AD8232

\section{METODE PENELITIAN}

\section{Tahapan Penelitian}

Penelitian ini dilakukan berdasarkan tahapantahapan penting yang dikerjakan dengan berorientasikan kepada indikator keberhasilan dalam menghubungkan nodemcu dengan sensor AD8232 sehingga dapat digunakan untuk menyelesaikan permasalahan multi objektif. Untuk dapat mencapai, indikator tersebut, maka tahapantahapan penelitian ini adalah sebagai berikut :

1. Analisa masalah, dalam hal ini kebutuhan menganalisa permasalahan yang akan diteliti mengenai smart healthcare.

2. Analisa kebutuhan, dalam hal ini segala kebutuhan dalam meneliti baik dari jurnal, buku, literatur-literatur, alat dan bahan.

3. Mendesain alat yang akan dibangun dengan menggunakan nodemcu beserta sensor AD8232.

4. Membuat program dengan menggunakan arduino IDE

5. Menguji alat dengan kode program yang dibuat.

6. Menguji alat yang dibuat dengan koneksi internet.

7. Membuat laporan dan menyimpulkan hasil penelitian

\section{Alat dan Bahan}

Dalam perencanaan dan pembuatan alat smart healthcare menggunakan nodemcu Perancangan perangkat keras meliputi pembuatan model pemasangan sensor AD8232 serta oled LCD. Bahan yang digunakan meliputi:

a. Perangkat Keras
1. NodeMcu
2. AD8232
3. Oled LCD 0.96"

b. Software yang digunakan untuk pembuatan sistem:

\section{Perancangan Sistem}

Desain dan implementasi alat smart healthcare memiliki langkah-langkah sebagai berikut :

1. Pengendali yang digunakan adalah Modul IoT NodeMcu

2. AD8231 yang digunakan untuk membaca denut jantung

3. Oled LCD yang digunakan untuk menampilkan grafik denyut jantung

4. Software yang digunakan adalah Arduino IDE untuk pemrograman modul Arduino

5. Blynk untuk membuat sistem berbasis Internet Of Things (IoT)

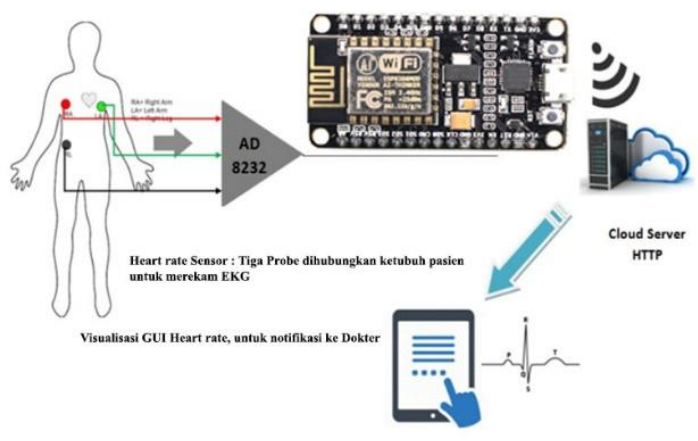

Gambar 1 Alur Kerja Sistem

\section{Cara Kerja:}

1. Sensor AD8231 digunakan untuk membaca denyut jantung pada tubuh manusia. Caranya dengan memasang tiga buah probe seperti pada gambar.

2. Oled LCD digunakan untuk menampilkan grafik denyut jantung pada layar.

3. Blynk digunakan untuk memberikan informasi denyut jantung di tampilkan pada smartphone android yang bertindak sebagai cloud server.

\section{HASIL DAN PEMBAHASAN}

Sensor AD8232 memiliki sembilan (9) pin out, pada penelitian ini hanya 5 pin yang digunakan. Tegangan yang digunakan sensor AD8232 adalah sebesar 3.3v. Berikut adalah tabel pin out yang digunakan:

Tabel 1 Pin out Sistem smart Healthcare

\begin{tabular}{|l|l|l|}
\hline Wemos & AD8232 & Oled \\
D1 Mini & & LCD \\
\hline
\end{tabular}




\begin{tabular}{|l|l|l|}
\hline & & $\mathbf{0 . 9}$ \\
\hline $3.3 \mathrm{v}$ & $3.3 \mathrm{v}$ & - \\
\hline 5v & - & $5 \mathrm{v}$ \\
\hline Gnd & Gnd & Gnd \\
\hline D7 & Lo + & - \\
\hline D8 & Lo - & - \\
\hline A0 & Output & - \\
\hline D1 & - & SCL \\
\hline D2 & - & SDA \\
\hline
\end{tabular}

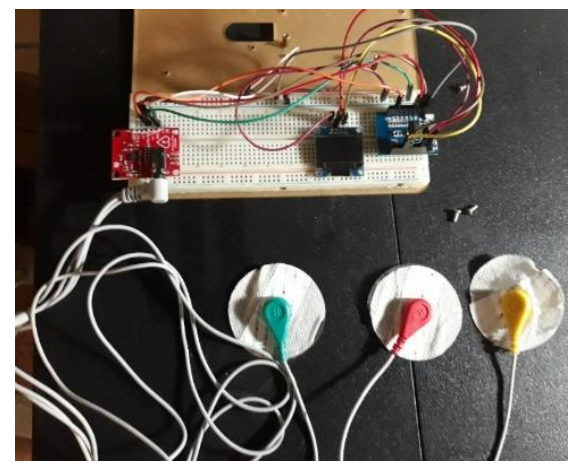

Gambar 1 Rancangan Alat Smart Healtcare

\section{Pengujian}

Pengujian alat dengan sensor AD8232 dengan cara memasang Elektroda seperti pada gambar 4.4. Agar hasil lebih bagus usahakan pengukuran dilakukan dengan keadaan tubuh terlentang dan dalam keadaan rileks. Pastikan tidak ada alat elektronik, cincin, kalung, dan logam lainya yang dapat menganggu pengukuran menempel pada tubuh yang diukur

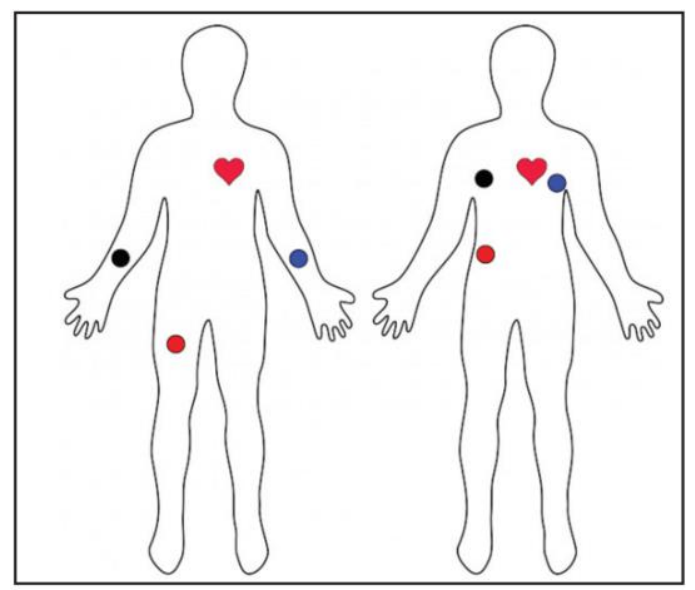

Gambar 2 Pemasangan posisi Elektrokardiograf

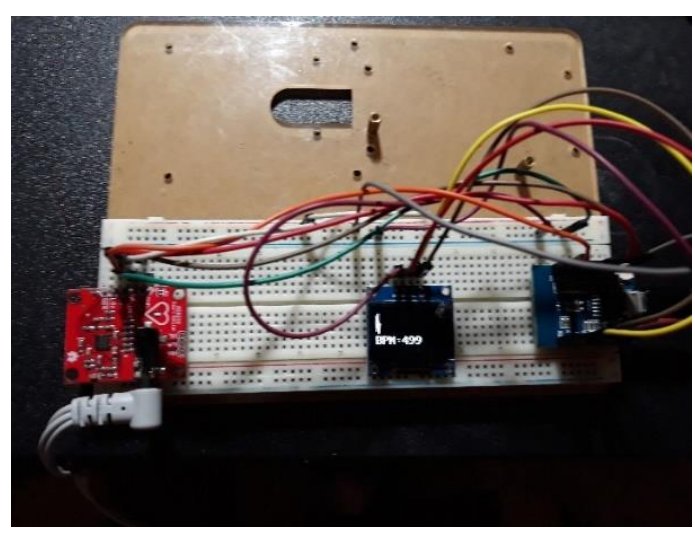

Gambar 4. 3 Hasil EKG di tampilkan pada oled LCD

Pada gambar di bawah merupakan pengujian menggunakan aplikasi blynk, dimana nilai EKG yang tampil dilayar LCD sama dengan nilai yang tertera pada aplikasi blynk di smartphone android. Sistem smart healthcare ini mengirimkan informasi ke dokter yang bersangkutan bersama dengan informasi pasien, sehingga dokter dapat melihat hasil EKG pasien secara langsung di smartphone.

Dengan demikian, sistem ini memiliki akses langsung 24 jam ke dokter untuk meninjau data yang dikirimkan dan membuat keputusan klinis mengenai pasien. Dokter dapat membantu pasien dalam keadaan darurat.

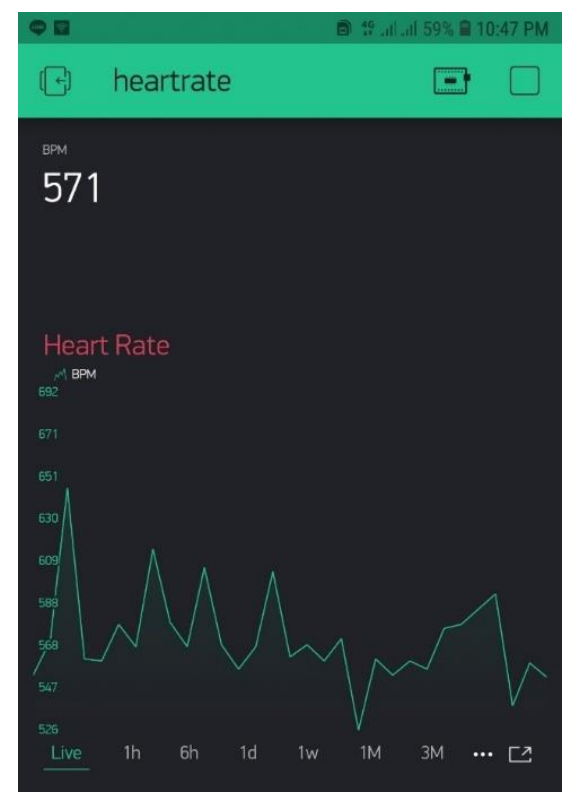

Gambar 4. 4 Pengujian EKG melalui aplikasi blynk 


\section{KESIMPULAN DAN SARAN \\ Kesimpulan}

Pada hasil uji coba dapat disimpulkan bahwa Hasilnya menunjukkan bahwa telah berhasil dibuat rancang bangun alat monitoring denyut jantung dengan tampilan berupa bentuk gelombang EKG, jumlah denyut jantung per menit, data di tampilkan melalui Icd dan smartphone android. Sistem smarthealtcare ini dapat menampilkan data EKG secara realtime dan dibuat dengan biaya yang murah serta sangat mudah dalam penggunaan nya.

Saran

Saran untuk penelitian kedepan ditambah penyimpanan dalam bentuk database yang datanya bisa disimpan secara online jadi konsultasi dengan dokter bisa online. Dalam penghitungan detak jantung menggunakan pengenalan sinyal, jadi hasil lebih akurat dalam penghitungan detak per menit.

\section{DAFTAR PUSTAKA}

Carlo Alberto Boano, Matteo Lasagni, Kay Romer, dan Tanja Lange. 2011 Accurate temperature measurements for medical research using body sensor networks.

Elizabeth, M. Cherry, Fenton, H. Flavio. 2003. Heart Structure, Function and Arrhythmias. Departement of Biomedical Science, College of Veterinary Medicine, Cornell University, Itacha. New York

Maureira, M. A. G., \& Teernstra, L. (2011). ThingSpeak - an API and Web Service for the Internet of Things.

Mehta, M. (2015). Esp 8266: a Breakthrough in Wireless Sensor Networks and, 6(8), 7-11.

P. Tirumala Rao, S. Koteswarao Rao , G. Manikanta and S. Ravi Kumar . Distinguishing Normal and

Abnormal ECG Signal .Indian Journal of sience and Technology, Vol 9(10), DOI:

10.17485/ijst/2016/v9i10/85449,

March 2016 ..

Sinha N, Ravi V. Implementation of health monitoring system using mixed environment. INDJST. 2015 Aug; $8(20)$.

Williams, B., 2007. Simple Guide: Tekanan Darah Tinggi.
Erlangga. Jakarta https://learn.sparkfun.com/tutorials/ad8232-heartratemonitorhookup-guide/all.pdf diakses pada tanggal 2 September 2018 pukul $16: 52$ 